\title{
MODEL DEVELOPMENT AND THE SHAPE OPTIMIZATION ANALYSIS OF A REAR KNUCKLE FOR RACE CAR
}

\author{
Yusop, M.S.M ${ }^{1}$, Lazim, M.S.M ${ }^{2}$, Razak, I.H.A ${ }^{3}$, Hashim, M.F \\ ${ }^{1}$ Universiti Kuala Lumpur, Malaysia France Institute, Seksyen 14, Jalan Teras Jernang, 43650 Bandar Baru Bangi, \\ Selangor, Malaysia \\ ${ }^{2}$ Universiti Kuala Lumpur, Malaysia France Institute, Seksyen 14, Jalan Teras Jernang, 43650 Bandar Baru Bangi, \\ Selangor, Malaysia \\ ${ }^{3}$ Universiti Kuala Lumpur, Malaysia France Institute, Seksyen 14, Jalan Teras Jernang, 43650 Bandar Baru Bangi, \\ Selangor, Malaysia \\ ${ }^{4}$ Institut Kemahiran Belia Negara Dusun Tua Batu 16, Dusun Tua, 43100 Hulu Langat, Selangor.Malaysia
}

\begin{abstract}
Automotive motorsport sector demands lightweight car component that directly contributes to fuel efficiency of a race car. Currently, EIMA Race Car got issues with the car weight. The current knuckle is heavy and did not undergo design process and analysis. The race cars need to compete with others in a 15 laps of endurance race. Refueling is prohibited during the race, thus it is very important to ensure the parts are in top condition and lightweight. By using the selected method and optimization tool for the rear knuckle, this paper looks into the design and development of a knuckle for EIMA race car. Solidworks has been used as a design tool and analysis process. The final design then undergoes an optimization process and the proposed design has been fabricated. The result can be considered successful as the new design is $70 \%$ lighter than the current rear knuckle.
\end{abstract}

Keywords: Product Design, simulation, race car knuckle, lightweight, optimization.

\section{INTRODUCTION}

Educational Innovation of Motorsports \& Automotive Race (EIMARace) is an inter-institutional program that opens to International and Public Higher Education Institute, Private Higher Education Institute, College, Polytechnics, \& Technical Institutions that highlight education through motorsports. EIMARace is a platform for students to apply the theory they learnt and improve their skills in the automotive sector indirectly. Participating in this competition, students will fabricate a functional prototype of a race car. The race car will be customized to suit the rules and regulation of the competition. Each of parts and components must be strong and lightweight to ensure the race car to compete in the endurance race.

This research focuses on design and development of a rear wheel knuckle for the race car. Knuckle is one of the important parts which contains the wheel hub or spindle, and attaches to the suspension components. It is variously called a steering knuckle, or hub. The wheel and tire assembly attach to the hub or spindle of the knuckle where the tire/wheel rotates while being held in a stable plane of motion by the knuckle and mounted securely onto the race car chassis [1].

A race car required lightweight and sturdy components to move fast [7]. A proper material selection will much improve the strength of the rear knuckle and the combination of lightweight materials for part will ensure the total weight of the race car can be reduced. Thus, the combination contributes the fuel efficiency to the optimal usage [2].

Optimization is a process to simplify a design to reduce the weight, manufacturing cost without reducing the initial strength of a part [3]. There are four disciplines of optimization process which are topology, shape, size and topography optimization. In the research, shape and size optimization was used to obtain the final optimum fillets, outer dimensions and thickness of the rear knuckle design [4].

The objective of the research is to study and investigate the current rear knuckle for the race car and to design a new rear knuckle that is light, sturdy using the optimization process.

\section{METHODOLOGY}

A series of study on the current knuckle has been done in the early stage of the research. Interview with the experts has been conducted to collect the important data. The expertise is from the different positions and work related in the race car team. Table 1 shows the experts information and details.

Table 1: Experts information

\begin{tabular}{|l|l|l|l|}
\hline Interviewees & Gender & Position & $\begin{array}{l}\text { Years of } \\
\text { Experience }\end{array}$ \\
\hline Expert A & Male & Designer & 3 \\
\hline Expert B & Male & $\begin{array}{l}\text { Race Team } \\
\text { Manager }\end{array}$ & 3 \\
\hline Expert C & Male & Engineer & 5 \\
\hline
\end{tabular}


The data and information gathered from the expertise were used as a main reference during the design and analysis. Solidworks was used as a design and analysis tool. The current rear knuckle was modeled and Finite element analysis (FEA) was carried out to evaluate the performance of the design. The analyzed data was set as a benchmark for the minimum requirements for the new rear knuckle design. Four (4) types of new rear knuckle design were modeled and analyzed to meet the requirements for the race car. Series of design validation has been done to choose the best design for the rear knuckle. The chosen design undergoes an optimization process to get the optimum shape and material usage. Solidthinking by Hyperwork was used to optimize the design. The optimized design was then remodeled in the Solidworks to get the accurate shape and dimension. Figure 1 shows the flow chart of the design process.

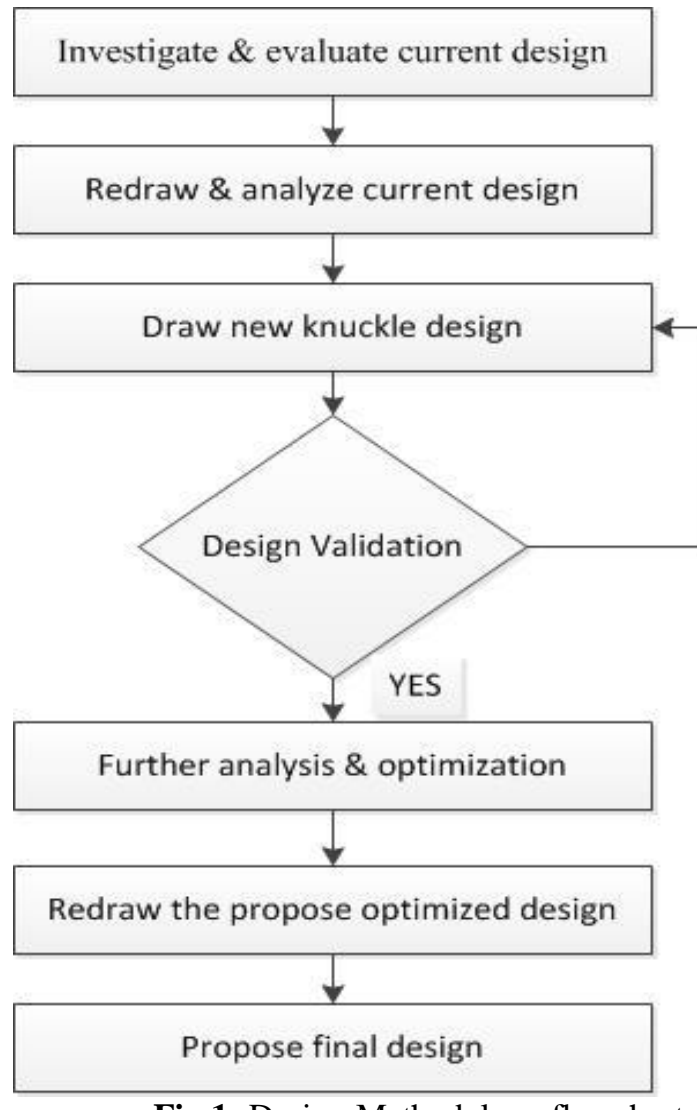

Fig.1: Design Methodology flowchart

\section{CONCEPTUAL DESIGN}

There are four (4) types of rear knuckle design has been modeled in the design tool. The concept design ideas and requirements were based on the parameters given by the Eimarace team. There are four (4) main parameters needs to be considered during the design process.

The first parameter is lightweight. Lightweight ensure the race car can accelerate and move faster. A lightweight design contributes to the fuel efficiency of the race car. Second parameter is the serviceability aspect. Technical race team requires an easy method to dismantle for servicing the parts and ergonomics was used for the new design. Third, the new design was checked parallel with a series of analysis simulation to improve the handle ability, response and stability for the new design. The new design need to be fabricated as easy as possible without secondary machining process that could affect the strength of the new design. Design tolerance [5] is also one of the important considerations as the rear knuckle is an assembled part where good alignment mates between parts are critical.

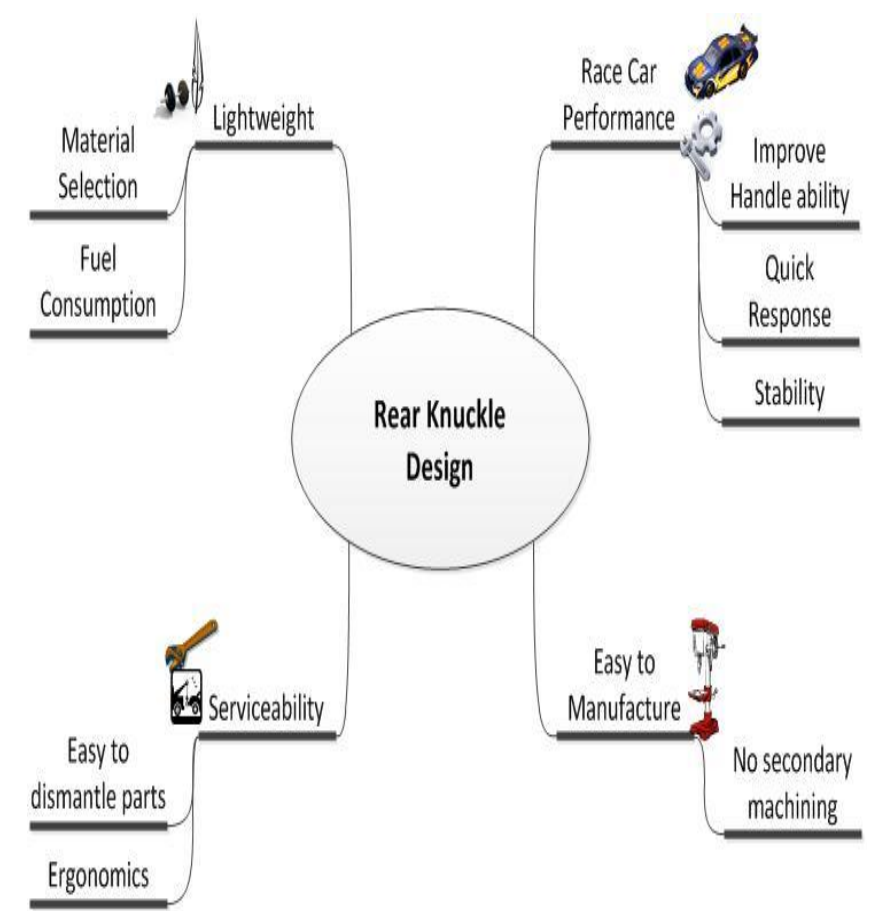

Fig 2: Rear Knuckle Design Parameters

Fig 3 below shows all four (4) designs based on the design parameters in Fig 2. These designs have been analyzed based on manufacturability, assembly and serviceability of the part. Each design was briefly discussed with the experts and results of the discussion were organized in Table 2. The table shows the summarized advantages and disadvantages of each rear knuckle designs.

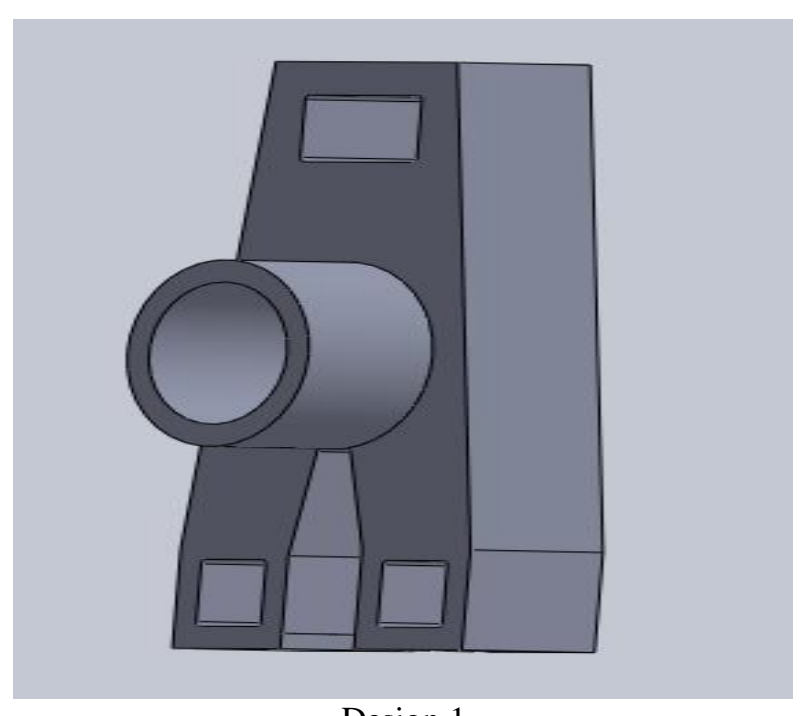

Design 1 


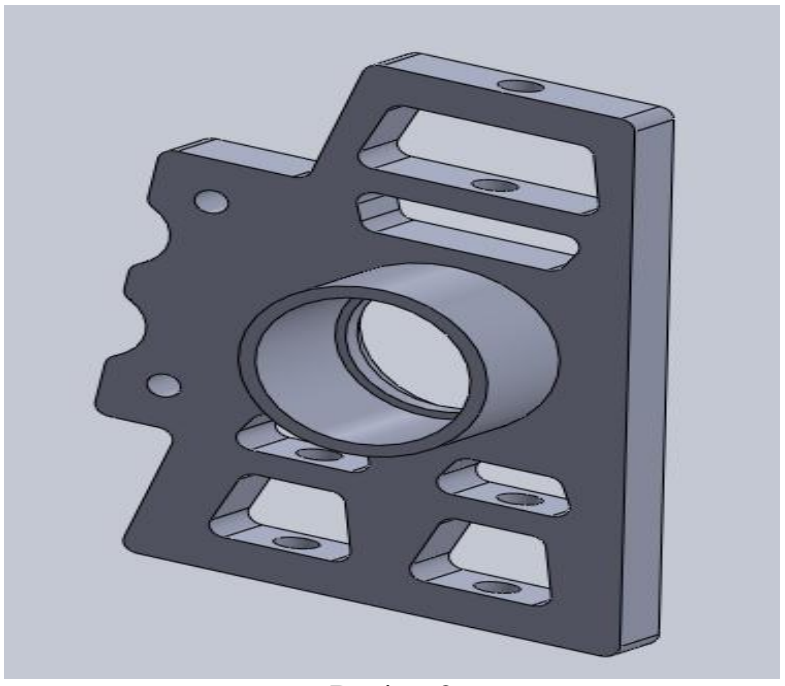

Design 2

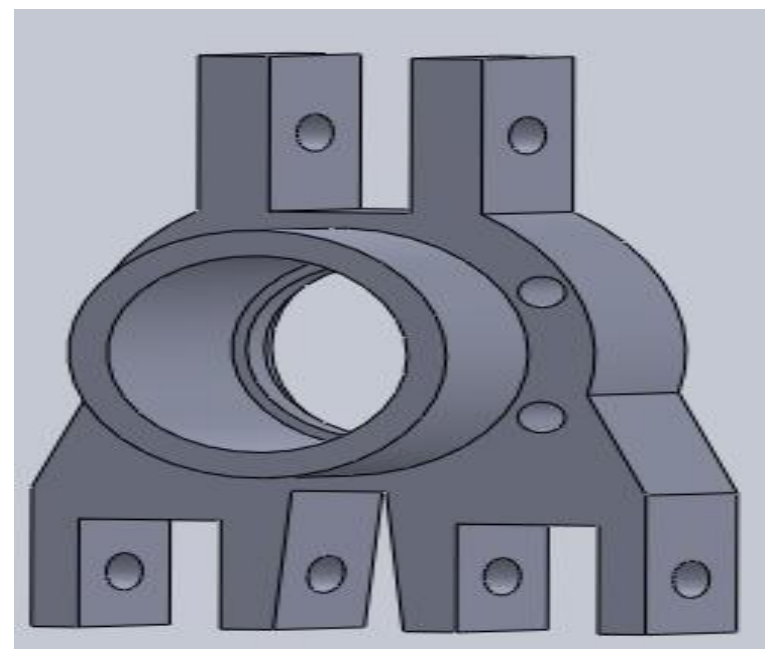

Design 3

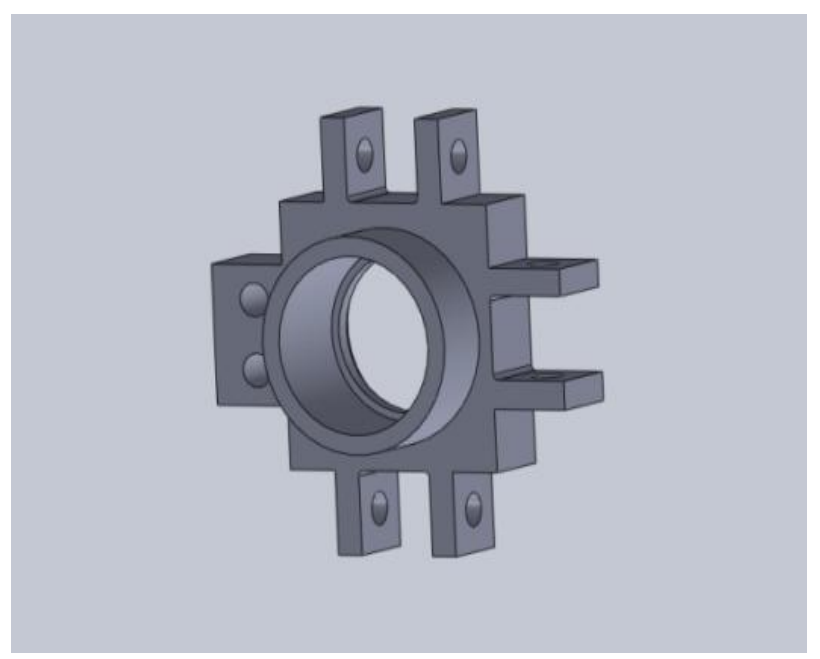

Design 4

Fig 3: Four (4) new rear knuckle design
Table 2: Advantages \& disadvantages of rear knuckle design

\begin{tabular}{|c|c|c|}
\hline Design & Advantage & Disadvantage \\
\hline Design 1 & $\begin{array}{l}\text { Easy to fabricate, no } \\
\text { complex shape. }\end{array}$ & $\begin{array}{l}\text { Difficult to assemble } \\
\text { the lower arm (the } \\
\text { space to insert lower } \\
\text { arm is smaller. Need } \\
\text { to consider the } \\
\text { diameter of race car } \\
\text { rims) }\end{array}$ \\
\hline Design 2 & $\begin{array}{l}\text { Easy to assemble the } \\
\text { lower arm. The } \\
\text { upper arm has been } \\
\text { enlarged. }\end{array}$ & The design is bigger. \\
\hline Design 3 & $\begin{array}{l}\text { Easy to assemble all } \\
\text { parts. }\end{array}$ & $\begin{array}{l}\text { Difficult to fabricate } \\
\text { because the radius. } \\
\text { The design has more } \\
\text { edges. }\end{array}$ \\
\hline Design 4 & $\begin{array}{l}\text { Easy to fabricate } \\
\text { because have no big } \\
\text { radius. } \\
\text { Easier to assemble } \\
\text { because the arm is } \\
\text { on the side of the } \\
\text { knuckle. }\end{array}$ & $\begin{array}{l}\text { Longer machining } \\
\text { process because the } \\
\text { edges in the design. }\end{array}$ \\
\hline Design 4 & $\begin{array}{l}\text { Easy to fabricate } \\
\text { because have no big } \\
\text { radius. } \\
\text { Easier to assemble } \\
\text { because the arm is } \\
\text { on the side of the } \\
\text { knuckle. }\end{array}$ & $\begin{array}{l}\text { Longer machining } \\
\text { process because the } \\
\text { edges in the design. }\end{array}$ \\
\hline
\end{tabular}

\section{MATERIAL SELECTION}

The current knuckle is made by mild steel. Mild steel offers good strength but it contributes more weight to the race car. The mild steel was substituted with Aluminum 6061 T6. This material offers a better strength and lightweight for the race car. Due to the low weight of the material [6], fuel consumption can be stretch to the optimum level. As per discussion with the experts, aluminum 6061 T6 was chosen due to the availability in Malaysian market and easy to machine. Table 3 below shows the mechanical properties of Aluminum 6061 T6.

Table 3: Material properties

\begin{tabular}{|l|l|}
\hline Properties & Value(Mpa) \\
\hline Elastic Modulus & 69000 \\
\hline Sheer Modulus & 26000 \\
\hline Yield Strength & 275 \\
\hline
\end{tabular}

\section{FEA ANALYSIS}

A series of FEA analysis was done to the four (4) knuckle design. The required load on the rear knuckle was determined from various past researches. According to [7], average weight of a passenger car is $400 \mathrm{~kg}$. The weight is 
distributed among all four knuckles. Eimarace car average weight is $250 \mathrm{~kg}$. Thus,

$=250 \mathrm{~kg} / 4=62.5 \mathrm{~kg}$, for each of the knuckle

$$
\begin{aligned}
\mathrm{W} & =\mathrm{mg} \\
& =62.5 \times 10=625 \mathrm{~N}
\end{aligned}
$$

Stress analysis was done on all four model shows in Figure 4. Initially, the fixture is fixed at the circle of the design, and then the force was applied on the model. The value of the load applied at the top and bottom is $312.5 \mathrm{~N}$ each. The displacement analysis were the analyzed on all model and the overall result was tabulate in table 4 for further analysis and to determine the best design for the Eimarace car.
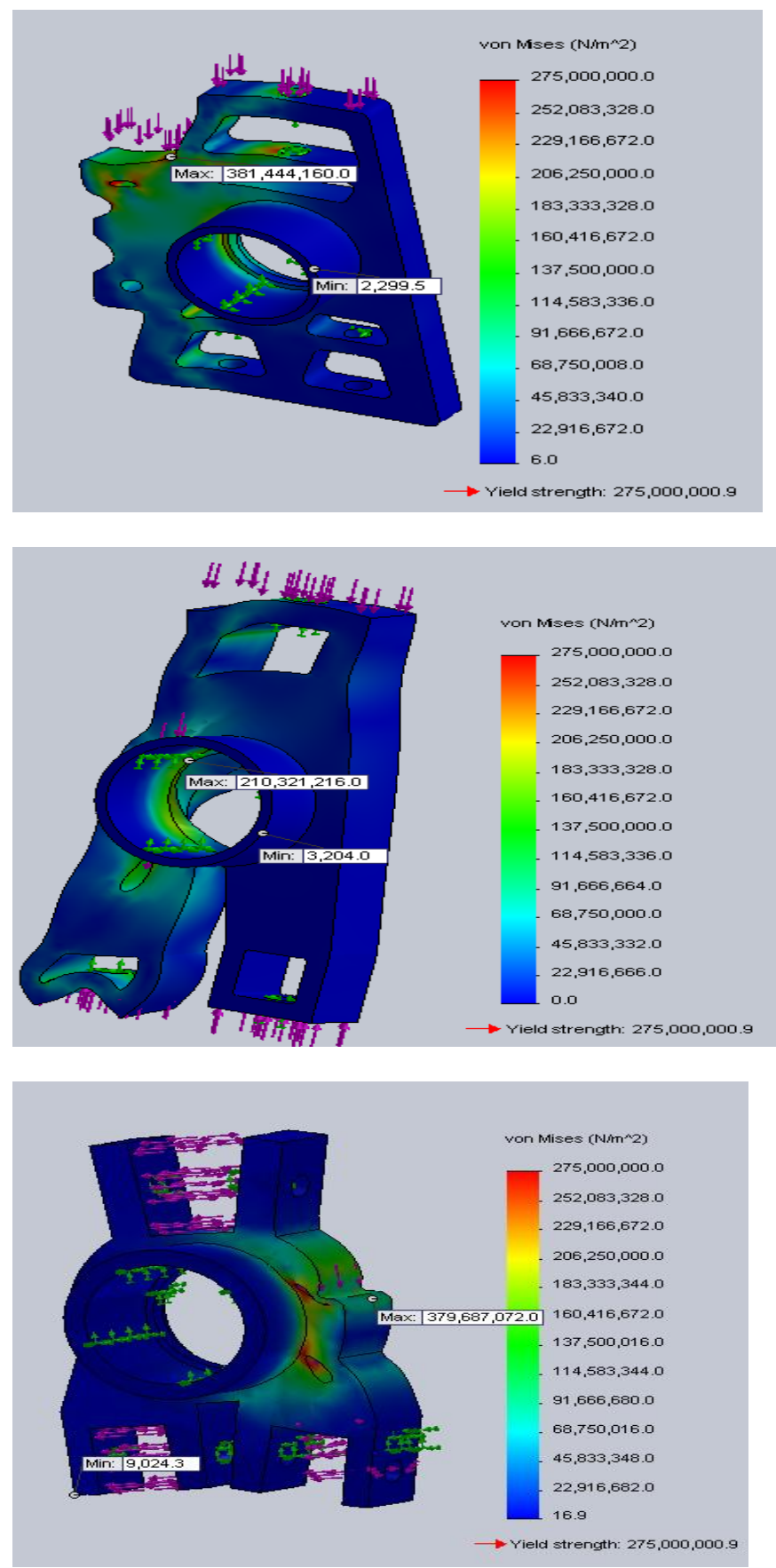

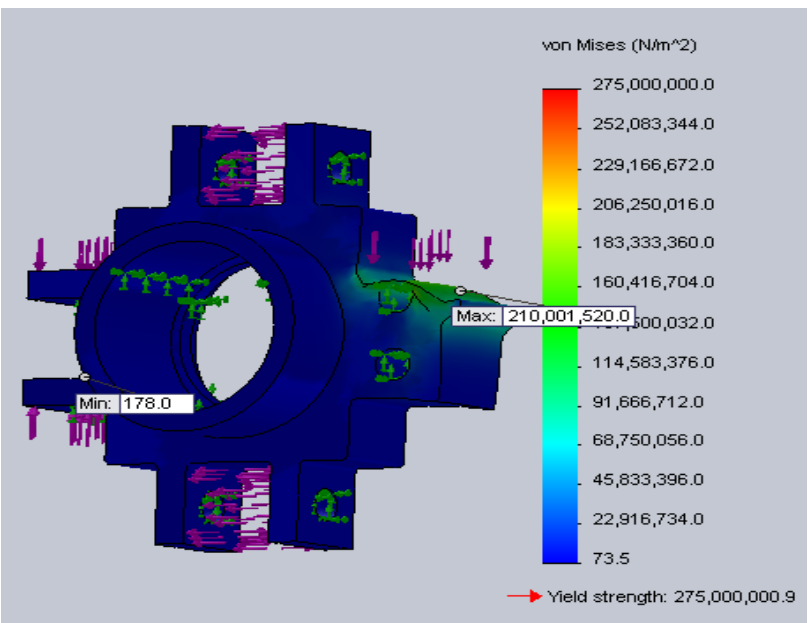

Fig 4: Stress analysis result

Table 4: Analysis Result

\begin{tabular}{|l|l|l|l|l|}
\hline & $\begin{array}{l}\text { Design } \\
1\end{array}$ & $\begin{array}{l}\text { Design } \\
2\end{array}$ & $\begin{array}{l}\text { Design } \\
3\end{array}$ & $\begin{array}{l}\text { Design } \\
4\end{array}$ \\
\hline $\begin{array}{l}\text { Stress } \\
\text { analysis } \\
\text { results (Mpa) }\end{array}$ & 210.3 & 381.4 & 379.6 & 210 \\
\hline $\begin{array}{l}\text { Displacement } \\
\text { results (mm) }\end{array}$ & 0.076 & 0.284 & 0.123 & 0.035 \\
\hline Mass (kg) & 1.7 & 1.9 & 1.5 & 1.5 \\
\hline
\end{tabular}

\section{OPTIMIZATION}

There are many optimization method offers to optimized a design. Shape optimization [2] is one of the methods to discover the optimal shape based on the model given in the software.

Design 4 was chosen for optimization process. The same analysis and load were applied in the optimization, and the software will automatically calculate and recommend the best optimal design for the rear knuckle. Figure 5 shows the optimization process in the Solidthinking software.

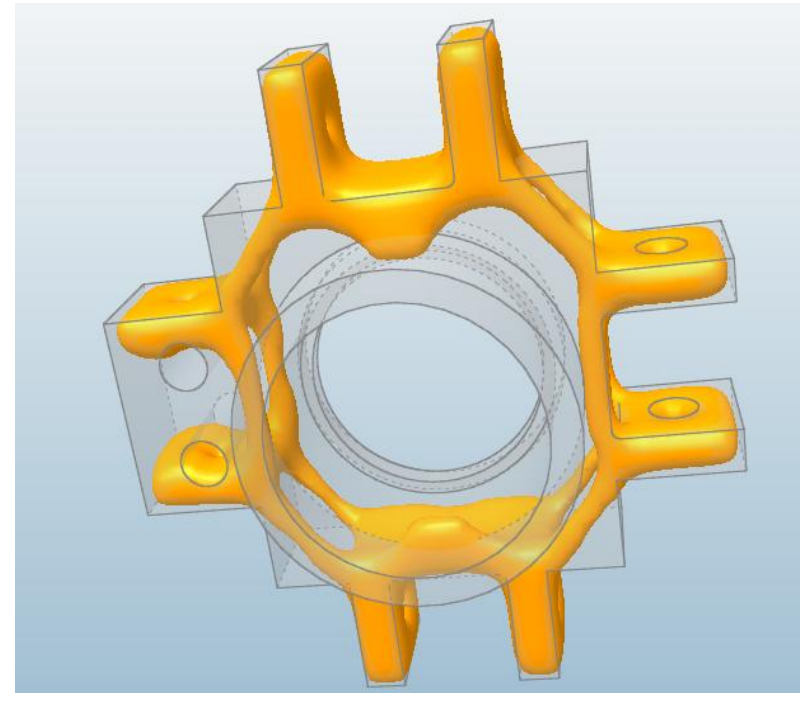




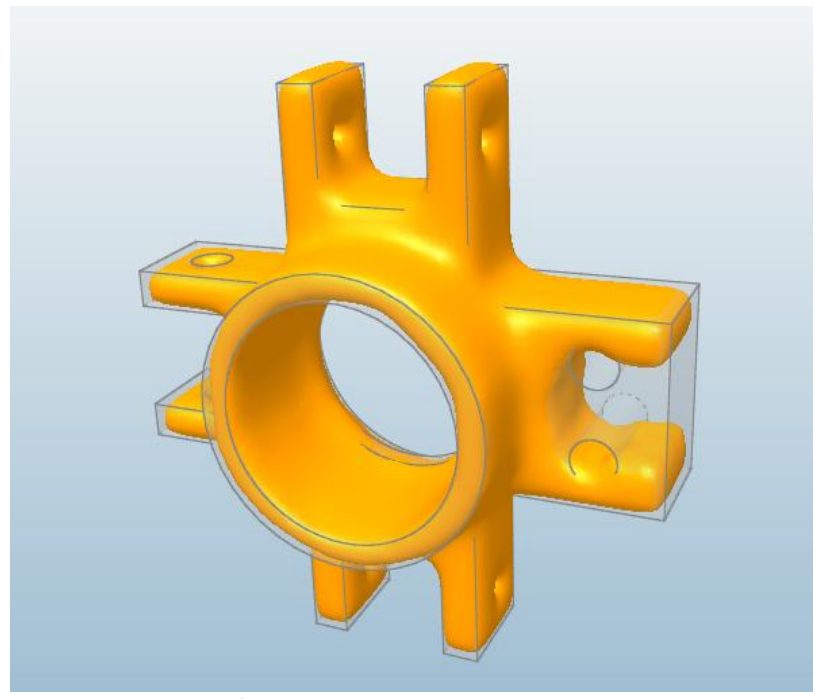

Fig 5: Optimization process

The optimized design was redrawn and reanalyzed again in the Solidworks software to get the actual dimension, shape and the analysis result. The result in table 5 shows improved figure after the optimization process. Figure 6 shows the final rear knuckle design.

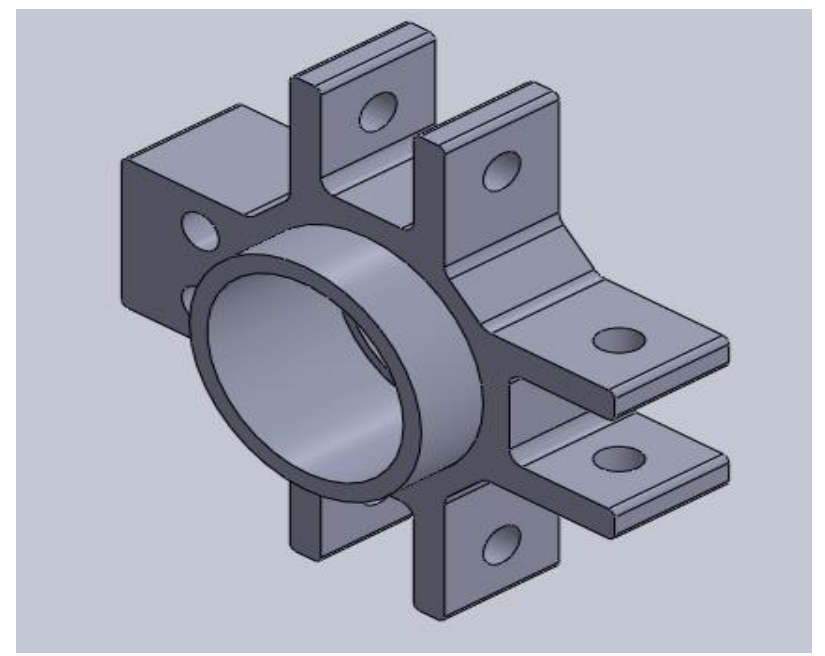

Fig 6: Optimized rear knuckle design

Table 5: Optimized design analysis result

\begin{tabular}{|l|l|}
\hline & New Design 4 \\
\hline $\begin{array}{l}\text { Stress analysis results } \\
(\mathrm{Mpa})\end{array}$ & 120.3 \\
\hline $\begin{array}{l}\text { Displacement results } \\
(\mathrm{mm})\end{array}$ & 0.00027 \\
\hline Mass $(\mathrm{kg})$ & 0.9 \\
\hline
\end{tabular}

\section{CONCLUSION}

The optimized rear knuckle design has been modeled and analyzed using Solidworks and SolidThinking software. The research shows the mass of the optimized design reduce by $52.6 \%$. The maximum stress and displacement are also improving even so the decreasing of the mass did not affect the stiffness of the structure. Therefore, the overall weight has been reduced to achieve the objectives of the race as well as improve the fuel consumption to the optimum usage.

\section{ACKNOWLEDGEMENTS}

Yusop M. S. M. thanks IKBN Dusun Tua, Selangor and Universiti Kuala Lumpur, Malaysia France Institute, to give this opportunity and the Final Year Project students for this research work.

\section{REFERENCES}

[1]. M. L. Syazwan, "Design and Development of Rear Knuckle for a Race Car". Final Year Project Report , January 2014

[2]. V.R. Kulkarni, A.G Tambe, "Optimization and Finite Element Analysis of Steering Knuckle", Altair Technology Conference, 2013

[3]. W.M. Wan Muhamad, E. Sujatmika, Hisham Hamid, F. Tarlochan, "Modeling, Simulation and Optimization Analysis on Steering Knuckle Component for Purpose of Weight Reduction", 2012

[4]. Y. Kojima, "Mechanical CAE in Automotive Design". R\&D review of Toyota CRLD, Vol. 35, No.4, 2000.

[5]. E. Gabriela, R. Carles, L. Joaquim, "An Approach to Avoid Quality Assembly Issues Since Product Design Stage". International Conference on Engineering Design, 2007

[6]. M.P. Sharma, D. S. Mevawala, H. Joshi, D. A. Patel, "Static Analysis of Steering Knuckle and Its Optimization". IOSR Journal of Mechanical and Civil Engineering, 2014, p.p 34-38

[7]. B. Babu, M. Prabhu, P. Dharmaraj, R. Sampath, "Stress Analysis on Steering Knuckle of the Automobile Steering System". International Journal of Research in Engineering and Technology, 2014

\section{BIOGRAPHIES}

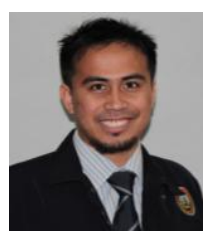

Yusop, M.S.M. is currently a lecturer in the Mechanical and Manufacturing Section at Universiti Kuala Lumpur Malaysia France Institute. His research interests include product design, mould technology and manufacturing.

E-mail:mshahrilmy@unikl.edu.my

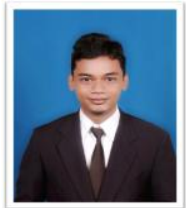

Lazim, M.S.M. graduated with a Bachelor of Engineering Technology in Machine Tools Manufacturing at Universiti Kuala Lumpur Malaysia France Institute. His research interests include product design and simulation.

E-mail: mohd_syazwann@yahoo.com

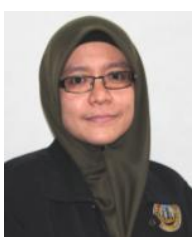

Razak, I.H.A. is currently a lecturer in the Mechanical and Manufacturing Section at Universiti Kuala Lumpur Malaysia France Institute. Her research interests include manufacturing system and design.

E-mail: izatulhamimi@unikl.edu.my 
Hashim, M.F. is currently a lecturer in the

Mechanical Department at Institut

Kemahiran Belia Negara, Dusun Tua. His

research interests include product design,

automotive and manufacturing.

E-mail: faisoul@kbs.gov.my 